\title{
POTENSI KUTIPAN ZAKAT PERNIAGAAN SYARIKAT TERSENARAI AWAM DI MALAYSIA
}

\author{
Zakāh on Business Potential from Public \\ Listed Companies in Malaysia
}

\author{
Adibah Abdul Wahab ${ }^{1}$ \\ Joni Tamkin Borhan ${ }^{2}$
}

\begin{abstract}
The purpose of this study is to estimate potential zakāh on business collection and to discover zakāh gap from public listed companies (PLCs) segment. This quantitative cross-sectional study examines the zakāh status of 817 Shariah compliant companies endorsed by Shariah Advisory Council of the Securities Commission (SC). Financial data is obtained through a census study from the latest annual report and another 705 annual reports were examined. This intensive study, based on the 30\% largest shareholder report, reveals that 118 companies are considered 'owned'by more than 30 percent of individuals who are Muslim. The total zakäh amount during the assessment of eligible companies was then used as the basis for determining 'zakāh potential'. As a result, the total
\end{abstract}

1 Ph.D Candidate, Department of Shariah and Economics, Academy of Islamic Studies, University of Malaya, 50603 Kuala Lumpur, adibahabdulwahab@gmail. com

2 Professor, Department of Shariah and Economics, Academy of Islamic Studies, University of Malaya, 50603 Kuala Lumpur, joni@um.edu.my 
potential of zakāh on businesses from PLCs is RM290 million per year. Concerning zakat payment, only 15 companies have zakāh disclosure in their financial reports and their total zakāh paid is RM76.8 million. This study also reveals gap of RM200 million yearly with a rate of 74 percent. Based on the tax gap rate (i.e around 7 percent) the 'zakāh gap' discovered is severe and the compliance rate among PLCs are still marginal. Thus, there is a great opportunity to further increase zakāh collection and strategic efforts need to be put in place by authorities and relevant parties in order to maximize zakāh collection in Malaysia.

Keywords: zakāh potential, zakāh on business, public listed companies, zakāh gap, zakāh compliance

\section{PENDAHULUAN}

Kewajipan membayar zakat perniagaan adalah sesuatu yang disepakati sejak daripada zaman Rasulullah SAW ${ }^{3}$ berdasarkan kepada dalil ayat suci al-Quran, hadis dan ijmak ulama. Nas yang menjadi asas kepada kewajipan membayar zakat perniagaan adalah sebagaimana firman Allah SWT:

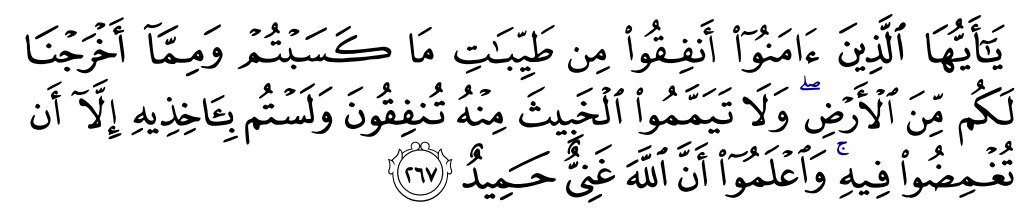

"Wahai orang yang beriman, nafkahkanlah (pada jalan Allah) sebahagian daripada hasil usaha kamu yang baik-baik, dan sebahagian daripada apa yang Kami keluarkan dari bumi untuk kamu. Janganlah kamu sengaja memilih yang buruk daripadanya, padahal kamu sendiri tidak sekali-kali akan mengambil yang buruk itu kecuali dengan memejamkan mata padanya. Ketahuilah, sesungguhnya Allah Maha Kaya lagi Maha Terpuji.",

(Surah al-Baqarah, 2: 267)

Imam Tabari, Imam Jashash, Imam Abū Bakr 'Arab̄i, Hasan dan Mujahid mentafsirkan istilah "hasil usaha yang baik-baik" di atas adalah merujuk kepada kekayaan diperoleh melalui hasil perdagangan. ${ }^{4}$

\footnotetext{
3 Sayyid Jamili, Fiqh al-Zakāh was Siyām li al-Imām Ibn Taymiyyah (Beirūt: Dār al-Fikr 'Arabī, 1996), 18.

4 Yūsuf al-Qaraḍāwī, Fiqh al-Zakāh, vol. 1, 341.
} 
Nas dalam bentuk hadis adalah sebagaimana hadis yang diriwayatkan oleh Abū Dawud iaitu dari Samrah bin Jundub berkata:

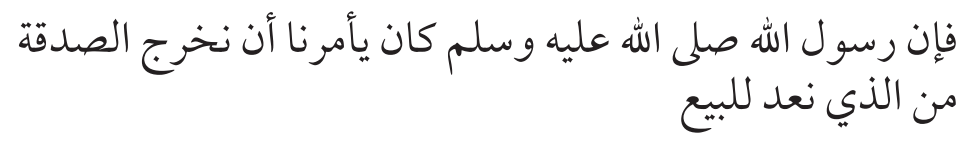

"Rasulullah SAW menyuruh kami untuk mengeluarkan zakat dari segala sesuatu yang kami persiapkan untuk dijual. " 5

Selain itu Saidina 'Umar bin al-Khatțab mengambil zakat dari harta perniagaan, dan tidak seorang pun sahabat yang menolaknya. Pandangan seperti ini turut diriwayatkan oleh Ibn 'Abbas, Ibn 'Umar, 'Umar bin 'Abd al'Azīz ${ }^{6}$ dan para ulama tabi' in juga telah bersepakat dalam hal ini. ${ }^{7}$

Zakat perniagaan atau dagangan berasal daripada kalimah 'arūd (العروض) adalah jamak kepada 'àraḍn (عارض). Ia bermaksud 'barang dalam dunia' selain emas dan perak sama ada ianya barang perhiasan, harta tidak alih, binatang, tanaman, pakaian dan sebagainya yang disediakan untuk perniagaan. Harta tidak alih yang disediakan oleh tuannya untuk berjual beli hukumnya sama seperti barang perniagaan. Ia wajib dikeluarkan zakat sebagai barang perniagaan. Manakala harta tidak alih yang didiami sendiri oleh tuannya atau dijadikan tempat kerjanya seperti tempat berniaga dan perusahaannya maka ia tidak dikenakan zakat. ${ }^{8}$

Imam Shāfi'ī meletakkan enam syarat ke atas harta yang dikenakan zakat perniagaan sebagaimana berikut:

a) Hendaklah barang perniagaan itu dimiliki dengan cara tukaran seperti jual beli dan bukan dengan cara lain

b) Hendaklah diniatkan yang barang itu untuk perniagaan semasa dilakukan kontrak jual beli

c) Jangan harta tersebut untuk kegunaan sendiri

d) Cukup hawl dari tarikh beli

5 Abū Dāwūd Sulaymān Ibn al-Ash'ath al-Sijistan dan 'Abd al-Ḥamīd Muḥammad Muhyy al-Dīn, Sunan Abū Dāwūd, vol. 2 (Beirūt: Dār al-Fikr, t.t.), 95. Hadis no. 1562 .

6 Yūsuf al-Qaraḍāwī, Fiqh al-Zakāh vol. 1, 344-345.

7 Ibn Qudāmah, Muwaffaq al-Dīn 'Abd Allāh Ibn Aḥmad, 1147-1223., Khattab, Muhammad Sharaf al-Dīn., Sayyid, al-Sayyid Muhammad, al-Mughn̄ wayalīhu al-Sharh al-Kabīr (Qāhirah: Dār al-Ḥadīth, 2004).

$8 \quad$ Wahbah al-Zuhaylī, al-Fiqh al-Islāmī wa Adillatuh, 787. 
e) Jangan seluruh harta itu menjadi wang sedangkan harta tersebut tidak cukup $n i s \bar{a} b$

f) Hendaklah nilai barangan mencapai nisab pada akhir hawl ${ }^{9}$

Permasalahan yang dihadapi oleh kajian ini adalah zakat perniagaan pula merupakan salah satu penyumbang utama kepada keseluruhan kutipan zakat negara. Salah satu permasalahan yang dihadapi adalah untuk mengetahui potensi sebenar kutipan zakat yang boleh dipungut daripada entiti perniagaan dan para peniaga yang layak. ${ }^{10}$ Oleh itu, kajian ini dibuat bagi memberikan petunjuk terhadap potensi kutipan zakat perniagaan dengan memilih segmen syarikat tersenarai awam (PLC) sebagai subjek kajian.

\section{OBJEKTIF}

Objektif utama kajian ini adalah bagi mendapatkan anggaran potensi sebenar kutipan zakat dan memahami realiti semasa trend pembayaran zakat perniagaan oleh PLC di Malaysia. Secara khususnya, kajian ini akan memberikan dapatan tentang jumlah kutipan yang boleh dipungut dan tahap kepatuhan zakat bagi segmen yang dikaji.

\section{KAJIAN LITERATUR}

\section{Prestasi Kutipan Zakat dan Zakat Perniagaan}

Kutipan zakat di Malaysia terus meningkat daripada RM423.8 juta pada tahun 2003 kepada RM1.936 bilion pada tahun 2012 iaitu peningkatan sebanyak RM1.512 bilion dengan peningkatan melebihi 300\% dalam jangka masa 10 tahun. Jumlah peningkatan setiap tahun meningkat begitu memberangsangkan daripada RM49 juta pada tahun 2003 hinggalah kepada RM294 juta pada tahun 2012. ${ }^{11}$ Rujuk Jadual 1.

\footnotetext{
9 Wahbah al-Zuhaylīi, al-Fiqh al-Islāmī wa Adillatuh, 788.

10 Mohd Rais Haji Alias, 'Business Zakat: Compliance and Practices in Federal Territory,' (Makalah National Business Zakat Symposium 2013, Kuala Lumpur, 17 September 2013), 2.

11 Pusat Pungutan Zakat MAIWP, Laporan Zakat (Kuala Lumpur: MAIWP, 2006 hingga 2012).
} 
Potensi Kutipan Zakat Perniagaan Syarikat Tersenarai Awam di Malaysia

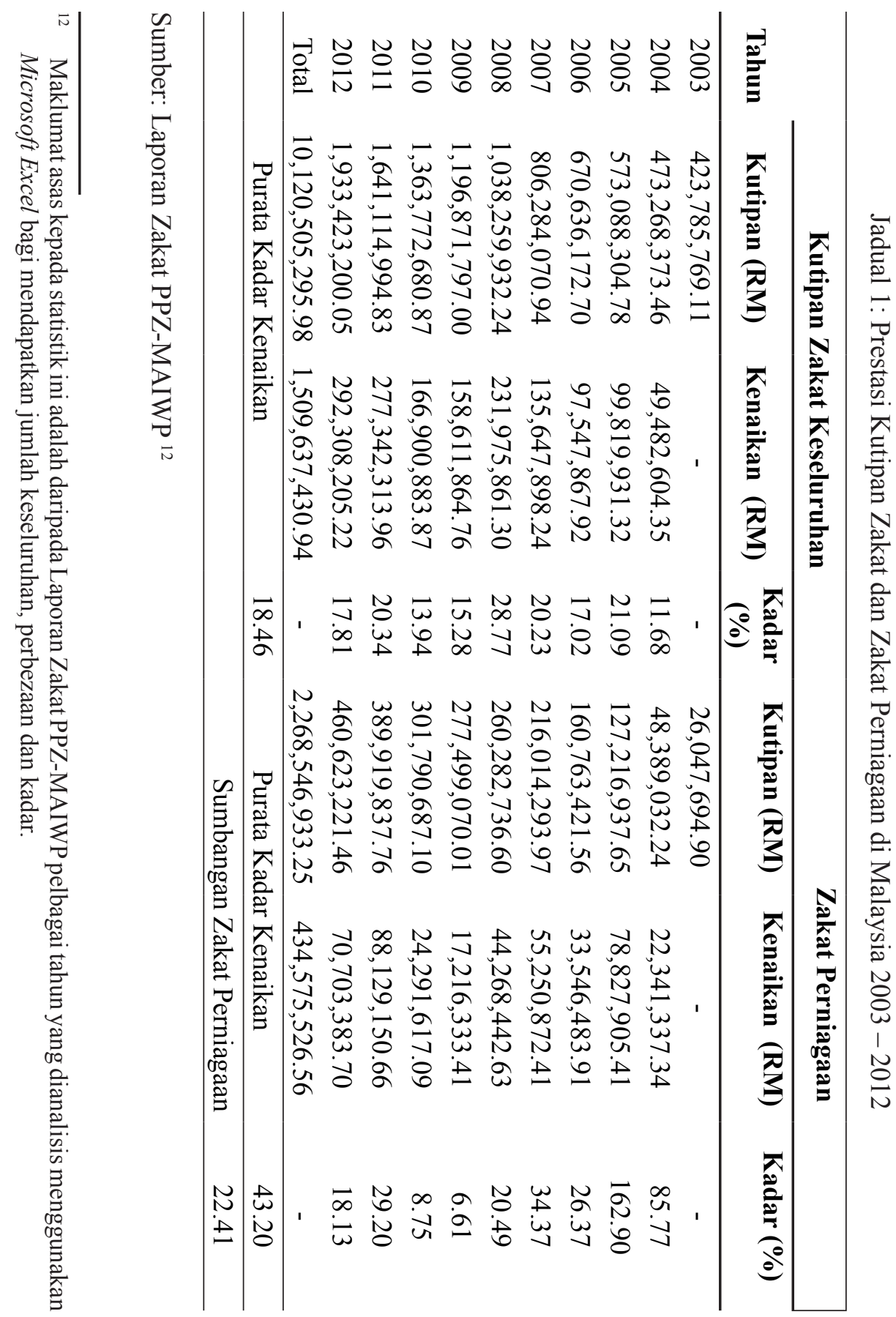


Kutipan zakat perniagaan di Malaysia juga meningkat daripada RM26 juta pada tahun 2003 kepada RM460.6 juta pada tahun 2012 iaitu peningkatan melebihi $1,700 \%$ dalam jangka masa 10 tahun. Purata kadar kenaikan setiap tahun adalah sebanyak $43.20 \%$ dan zakat perniagaan menyumbang sebanyak $22.41 \%$ daripada jumlah kutipan zakat di Malaysia.

Bilangan pembayar zakat di Malaysia juga terus meningkat daripada 426, 207 orang pada tahun 2006 kepada 889,509 pada tahun 2012 iaitu peningkatan sebanyak 463,302 dengan peningkatan melebihi 100\% dalam jangka masa 6 tahun. Jumlah peningkatan setiap tahun meningkat begitu memberangsangkan daripada 26,378 orang pada tahun 2006 kepada 128,089 orang pada tahun 2012. ${ }^{13}$ Rujuk Jadual 2.

Jadual 2: Prestasi Pembayar Zakat dan Zakat Perniagaan

\begin{tabular}{ccccccc}
\hline Tahun & $\begin{array}{c}\text { Pembayar } \\
\text { Zakat Harta } \\
\text { (Bil) }\end{array}$ & $\begin{array}{c}\text { Kenaikan } \\
\text { (Bil) }\end{array}$ & Kadar & $\begin{array}{c}\text { Pembayar } \\
\text { Zakat } \\
\text { Perniagaan } \\
\text { (Bil) }\end{array}$ & Kenaikan & Kadar \\
\hline 2006 & 426,207 & - & - & 15,653 & - & - \\
2007 & 452,585 & 26,378 & 6.19 & 18,085 & 2,432 & 15.54 \\
2008 & 586,533 & 133,948 & 29.60 & 18,197 & 112 & 0.62 \\
2009 & 662,710 & 76,177 & 12.99 & 20,492 & 2,295 & 12.61 \\
2010 & 694,041 & 31,331 & 4.73 & 32,350 & 11,858 & 57.87 \\
2011 & 761,420 & 67,379 & 9.71 & 23,246 & $-9,104$ & 28.14 \\
2012 & 889,509 & 128,089 & 16.82 & 26,796 & 3,550 & 15.27 \\
Total & $4,473,005$ & 463,302 & & 154,819 & 11,143 & 73.76 \\
\hline Purata & & & 13.34 & Purata & & 12.30 \\
Kenaikan & & & & Kenaikan & & \\
\hline
\end{tabular}

Sumber: Laporan Zakat PPZ-MAIWP ${ }^{14}$

Manakala bilangan pembayar zakat perniagaan terus meningkat daripada 15,653 pembayar pada tahun 2006 kepada 26,769 pembayar pada tahun 2012 iaitu peningkatan sebanyak 11,143 dengan peningkatan sebanyak $71 \%$ dalam

13 Pusat Pungutan Zakat MAIWP, Laporan Zakat (Kuala Lumpur: MAIWP, 2006 hingga 2012).

14 Maklumat asas kepada statistik ini adalah daripada Laporan Zakat PPZ-MAIWP pelbagai tahun yang dianalisis menggunakan Microsoft Excel bagi mendapatkan jumlah keseluruhan, perbezaan dan kadar. 
jangka masa 6 tahun. Peningkatan setiap tahun adalah baik iaitu daripada 2,432 pembayar orang pada tahun 2006 kepada 3,550 pembayar pada tahun 2012. ${ }^{15}$

\section{Status Kewajipan Membayar Zakat Oleh PLC}

Status kewajipan membayar zakat adalah jelas dalam konteks kewajipan individu atau entiti perseorangan (individual entity, natural person, shakhșiyyah 'adiyah). Walau bagaimanapun dalam konteks syarikat perkara ini menjadi lebih rumit kerana syarikat dikategorikan sebagai shakhșiyyah i itibāriah atau legal entity kerana institusi korporat (termasuk PLC) tidak mempunyai ciri-ciri individu secara total (individual entity). ${ }^{16}$ Oleh itu terdapat banyak perbincangan mengenai kewajipan zakat oleh entiti perundangan seperti PLC kerana zakat diwajibkan ke atas individu muslim sedangkan PLC adalah entiti yang tidak mempunyai status agama. ${ }^{17}$

Jawatankuasa Fatwa melalui Muzakarah Jawatankuasa Fatwa Majlis Kebangsaan Bagi Hal Ehwal Ugama Islam Malaysia Kali Ke-31 yang bersidang pada 9 Disember 1992 telah membincangkan Zakat Ke Atas Syarikat. Muzakarah telah memutuskan bahawa syarikat perniagaan adalah diwajibkan zakat apabila mencukupi syarat-syarat berikut: ${ }^{18}$

a) "Perniagaan yang dimiliki oleh orang Islam."

b) "Perniagaan dimiliki oleh orang Islam yang merdeka."

c) "Sempurna milik."

d) "Cukup nisab."

e) "Cukup hawl (genap setahun qamariah/354.3 hari)"

f) "Kadar zakat ke atas syarikat tersebut adalah 2.5\%."

Jawatankuasa Fatwa menjelaskan bahawa:

15 Pusat Pungutan Zakat MAIWP, Laporan Zakat (Kuala Lumpur: MAIWP, 2006 hingga 2012).

16 Aznan Hasan, 'Zakat on Shakhșiyyah i'itibāriah (Legal Entity),' (Makalah, Bengkel Zakat Institusi Kewangan Islam, Lanai Kijang, Bank Negara Malaysia, 3 Mei 2011).

17 The New Straits Times, 'Zakat Not for Companies, says Tun Abdul Hamid,' 4 Julai 2013, http://www.nst.com.my/latest/zakat-not-for-companies-says-tunabdul-hamid-1.313162\#ixzz2o911Anhr, diakses pada 21 Disember 2013.

18 'E-fatwa,' Jabatan Kemajuan Islam Malaysia, http://www.e-fatwa.gov.my/fatwakebangsaan/zakat-ke-atas-syarikat, diakses pada 21 Disember 2013. 
"Syarikat yang dimiliki bersama antara orang Islam dan bukan Islam, maka wajib ke atas jumlah saham yang dimiliki oleh orang Islam sahaja...." 19

Asas kepada pengenaan zakat ini adalah bersandarkan kepada sebuah hadis Rasulullah SAW iaitu:

$$
\text { و لا يجمع بين متفرقلا يفرق بين بجتمع خخافة الصدقة }
$$

"Dan tidak terhimpun antara yang terpisah dan tidak terpisah antara yang terhimpun kerana takut bersedekah (zakat)" 20

Berdasarkan hadis ini dapat disimpulkan bahawa beberapa individu yang berada dalam satu syarikat atau perkumpulan maka dianggap satu tanpa dipisah-pisahkan antara satu sama lain. Apabila sebuah syarikat ditubuhkan dengan niat untuk menjalankan perniagaan sama ada syarikat perkhidmatan, syarikat guaman, perhotelan, runding cara, perubatan, rekreasi, cari gali dan sebagainya, maka syarikat tersebut dianggap syarikat perniagaan yang dikenakan zakat perniagaan.

Prinsip fiqh yang digunakan di sini menggunakan konsep khultah. Khultah terbahagi kepada dua iaitu:

a. Khultah al-Syuy $\bar{u}$ ' iaitu berlaku percampuran yang menyebabkan tidak dapat dibezakan milikan masing-masing

b. Khulțah al-Jiwār iaitu berlaku percampuran pemilikan yang masih dapat dibezakan pemilikan masing-masing. ${ }^{21}$

Menurut Muhammad Taqi Usmani pengiraan zakat dalam kalangan PLC adalah menggunakan prinsip Khulțh al-Syuy $\bar{u}$ ' di mana percampuran pemilikan adalah tidak dapat dibezakan. Dalam konteks ini, kewajipan berzakat tidak dikenakan atas individu perseorangan tetapi individu perundangan (judicial person). Individu perseorangan tidak dipertanggungjawabkan secara langsung dalam hal ini tetapi perkongsian pegangan (joint stock). Ini bermakna perkongsian pegangan dikira sebagai pemilikan tidak terpisah dan tanggung

19 'E-fatwa,' Jabatan Kemajuan Islam Malaysia, http://www.e-fatwa.gov.my/fatwakebangsaan/zakat-ke-atas-syarikat, diakses pada 21 Disember 2013.

20 Abū Dāwūd Sulaymān Ibn al-Ash'ath al-Sijistan dan 'Abd al-Ḥamīd Muhammad Muhy al-Dīn, Sunan Abū Dāwūd, vol. 2 (Beirūt: Dār al-Fikr, t.t.), 99. No. hadis 1571; Hadis riwayat al-Bukhārī, Șaḥịh Bukhārī, vol. 4. no. hadis 1382, terj. Syed Ahmad Semait (Kuala Lumpur: Pustaka Nasional, 2006), 1812.

21 Panduan Zakat Perniagaan (Shah Alam: Lembaga Zakat Selangor, 2008), 29. 
jawab menunaikan zakat dipindahkan kepada entiti yang mempunyai ciri yang hampir sama dengan individu perundangan walaupun tidak sama sepenuhnya. ${ }^{22}$

Walaupun pemilikan salah seorang tidak mencukupi nisab, nilai yang diambil adalah nilai terkumpul kerana kewajipan zakat dikenakan bukan atas tanggungjawab seseorang individu, tetapi atas perkongsian harta yang kini dikira sebagai satu entiti. ${ }^{23}$ Adalah menjadi kewajipan syarikat perniagaan mengeluarkan zakat bagi pihak pemiliknya dan sekiranya syarikat tersebut tidak mengeluarkan zakat, maka pemiliknya hendaklah mengeluarkan zakat secara persendirian. Syarikat perkongsian antara orang Islam dan bukan Islam, maka zakat hanya dikeluarkan berdasarkan saham milik orang Islam sahaja. ${ }^{24}$

Dalam kajian yang dibuatoleh Malik M. Hafeez, beliau membuat kesimpulan bahawa maksud perkataan seseorang (person) adalah digunakan kebiasaannya untuk individu manusia tetapi dalam konteks perundangan, ia mempunyai istilah teknikal yang membawa maksud hak dan kewajipan. Undang-undang mengiktiraf status individu perundangan (legal person) sebagai entititi yang sah seperti sesebuah dana dan syarikat. Walaupun individu perundangan ini mungkin merupakan individu perundangan yang bukan asli (artificial juristic person), tetapi ia boleh menerima pertanggungjawaban seperti memiliki harta dan menjalankan perniagaan sama seperti individu perseorangan yang sebenar. Institusi Baitulmal, wakaf dan masjid merupakan contoh pengiktirafan Islam terhadap entiti perundangan ini. ${ }^{25}$ Oleh itu, kajian ini mengguna pakai rasional di atas yang dikukuhkan oleh Fatwa Kebangsaan bahawa syarikat adalah entiti wajib mengeluarkan zakat.

\section{Potensi Kutipan Zakat}

Istilah potensi yang dimaksudkan dalam kajian ini adalah merujuk potensi pasaran (market potential). Potensi pasaran ini ditakrifkan sebagai jumlah individu atau perniagaan yang berpotensi untuk membeli/melanggan sesuatu produk atau perkhidmatan. Ia juga bermaksud jumlah maksimum

22 Muhammad Taqi Usmani, An Introduction to Islamic Finance (Karachi: Idaratul Ma'arif, 1998), 157.

23 Muhammad Taqi Usmani, An Introduction to Islamic Finance, 156 -157.

24 'E-fatwa,' Jabatan Kemajuan Islam Malaysia, http://www.e-fatwa.gov.my/fatwakebangsaan/zakat-ke-atas-syarikat, diakses pada 21 Disember 2013.

25 Malik M. Hafeez, 'An Analysis of Corporate Entity and Limited Liability in Islamic and Western Perspectives of Corporate Governance,' International Journal of Business, Economics and Law, 2/3 (2013): 104-107. 
pelanggan. ${ }^{26}$ Terdapat beberapa kajian mengenai potensi kutipan zakat atau unjuran mengenai kutipan zakat dilakukan di beberapa negara berdasarkan kepada angka-angka tertentu yang didapati relevan dengan sesebuah negara. Antara kajian yang paling awal yang pernah dibuat adalah di Mesir oleh Sami Ramadan Sulaiman ${ }^{27}$ yang membuat anggaran potensi kutipan zakat adalah sebanyak 6.1\% daripada Keluaran Dalam Negara Kasar (KDNK). Unjuran ini dihasilkan dengan membuat anggaran kutipan mengikut sektor utama dalam ekonomi yang merangkumi sektor perkhidmatan, industri, perdagangan dan pertanian. Sektor industri dan perdagangan yang mempunyai kadar pulangan yang lebih tinggi berbanding sektor lain dengan anggaran zakat bagi sektor ini adalah sebanyak $8.8 \%$. Manakala bagi sektor perkhidmatan, beliau membuat unjuran dengan mengambil kira 50\% daripada tenaga buruh di Mesir layak membayar zakat. Bagi zakat pertanian (termasuk ternakan), anggaran kutipan zakat adalah 9.5\% daripada kadar KDNK. ${ }^{28}$

Monzer Kahf telah membuat anggaran potensi kutipan zakat di lapan negara Islam menggunakan tiga jenis definisi harta yang dikenakan zakat. Definisi pertama, $Z_{1}$ mengandungi hasil pertanian, ternakan, harta dagangan dan wang simpanan. Definisi kedua, $Z_{2}$ ialah harta yang dipersetujui oleh ramai pihak iaitu $Z_{1}$ dan harta lain yang lebih kontemporari iaitu pendapatan hasil harta tetap dan penggajian juga mengambil kira kos sara diri. Manakala definisi ketiga $\mathrm{Z}_{3}$, merangkumkan kesemua termasuk nilai harta tetap dalam semua sektor pada kadar 2.5\%. Melalui kaedah ini Kahf menganggarkan jumlah kutipan yang boleh dikutip daripada Keluaran Negara Kasar (KNK) adalah $1 \%$ hingga $2 \%$ bagi $Z_{1}, 3.1 \%-4.9 \%$ daripada $K N K$ bagi $Z_{2}$ dan $3.2-6.2 \%$ bagi $\mathrm{Z}_{3}{ }^{29}$

Nasim Shah Sirazi ${ }^{30}$ telah memanfaatkan kajian Kahf bagi mendapatkan anggaran potensi kutipan zakat dalam kalangan 38 buah negara OIC termasuk

26 Kenneth E. Clow \& Donald Baack, Marketing Management: A Customer-Oriented Approach (Carlifornia: Sage Publcation Inc, 2010), 44

27 Sami Ramaḍān Sulaymān, 'al-Asās al-Muhāsabiyyah li taqdīr hāṣilāt al-Zakāh: Dirāsah Tatbīqiyah fi Jumhūriyah Mișr al- ‘Arabiyah,' (Tesis Ph.D, Universiti alAzhar, 1980).

28 Monzer Kahf, 'The Performance of Zakah Institution in Theory and Practice,' (Makalah, International Conference on Islamic Economics Towards the $21^{\text {st }}$ Century, Kuala Lumpur: 9-12 Ogos 1999), 22.

29 Monzer Kafh, 'The Performance of Zakah Institution in Theory and Practice,' 2324.

30 Nasim Shah Sirazi \& Md Fouad, 'Prospects Elimination Through Potential Zakat Collection in OIC-member Countries: Reappraised,' Journal of Islamic Economics, Banking and Finance, 6/3 (2010): 66. 
Malaysia. Hasil kajiannya yang dibuat pada tahun 2004 di Malaysia mendapati potensi kutipan zakat Malaysia berdasarkan $Z_{1}$ adalah sebanyak USD3,010.88 juta (RM9,634.80 juta), $Z_{2}$ sebanyak USD 6,439.94 juta (RM20,608 juta) dan $\mathrm{Z}_{3}$ adalah sebanyak USD7,259.57juta (RM23,231 juta). ${ }^{31}$

Kajian lain yang dibuat adalah di Indonesia. ${ }^{32}$ Kajian ini dibuat melalui data primer yang diperoleh daripada 354 buah isi rumah. Manakala data sekunder pula diperoleh daripada pelbagai sumber. Melalui analisis empirikal, potensi kutipan zakat di Indonesia adalah sebanyak 217 trillion rupiah yang bersamaan 3.4\% daripada Keluaran Negara Kasar Indonesia.

Mohd Rais Alias membuat unjuran potensi kutipan zakat yang baik kerana ia dibuat berdasarkan kepada bilangan syarikat yang didaftarkan oleh Suruhanjaya Syarikat Malaysia (SSM). Beliau mendapati terdapat lebih 5 juta perniagaan dan syarikat yang didaftarkan. Dengan mengambil purata ekuiti pemilikan bumiputera kajian ini menganggarkan potensi kutipan zakat perniagaan adalah sebanyak RM240.1 juta bagi tahun 2010, RM441.6 juta bagi tahun 2011 dan RM541.9 juta bagi tahun 2012. ${ }^{33}$ Andaian yang dibuat adalah ekuiti pemilikan bumiputera adalah sebanyak 30\% dan tahap kelayakan membayar zakat juga adalah 30\%.

Hampir semua penyelidikan di atas menggunakan KNK atau KDNK sebagai asas anggaran dan ini bersesuaian dengan hasrat kajian mereka untuk melihat di peringkat ekonomi makro. Kajian yang dibuat oleh Mohd Rais Alias pula adalah berdasarkan kepada anggaran umum daripada bilangan syarikat yang berdaftar. Oleh itu, belum ada lagi kajian yang mengkaji potensi kutipan zakat berdasarkan bancian sebenar terhadap sesuatu populasi. Oleh itu, kajian ini dibuat secara terperinci dengan mengkaji kelayakan membayar zakat bagi setiap unit dalam populasi kajian.

31 Kajian ini menggunakan USD sebagai ukuran dan penyelidik membuat tukaran matawang daripada USD kepada Ringgit Malaysia pada kadar RM3.20 iaitu kadar tukaran pada 11 Disember 2013.

32 Muhammad Firdaus, Irfan Syauqi Beik, Tonny Irawan \& Bambang Juanda, 'Economic Estimation and Determinations of Zakat Potential in Indonesia,' (IRTI Working Paper Series, Islamic Research and Training Institute, Islamic Develompen Bank, Jeddah, 2012), 65.

33 Mohd Rais Haji Alias, 'Business Zakat: Compliance and Practices in Federal Territory,' 15. 


\section{Jurang Zakat}

Kajian ini memperkenalkan istilah iaitu jurang zakat. Konsep jurang zakat dalam kajian ini adalah mirip kepada jurang cukai atau lebih dikenali dengan istilah tax gap. Jurang cukai adalah perbezaan di antara potensi penuh hasil cukai yang sepatutnya dibayar kepada negara dan jumlah kutipan cukai sebenar yang dipungut. ${ }^{34}$

Kerajaan Britain menggunakan jurang cukai bagi mengukur prestasi kutipan cukai negara. Satu laporan yang dinamakan Measuring Tax Gap dikeluarkan setiap tahun bagi melaporkan tahap kepatuhan cukai oleh pembayar cukai negara. Bagi tahun 2013 jurang cukai di Britain adalah sebanyak $£ 35$ bilion iaitu bersamaan 7\% daripada jumlah cukai dan bagi tahun 2012 jurang cukai adalah $£ 34$ bilion bersamaan $7.1 \%{ }^{35}$

Kerajaan Amerika Syarikat juga membuat anggaran jurang cukai melalui Internal Revenue Service (IRS) bagi tempoh tertentu dan yang terkini adalah sehingga 2006 yang dikeluarkan pada tahun 2012. Jumlah jurang cukai bersih (Net Tax Gap) di Amerika Syarikat adalah $\$ 385$ bilion dengan kadar kepatuhan $85.5 \%$. Kadar Kepatuhan ini didapati meningkat berbanding dengan kajian sebelum ini yang dibuat pada tahun 2001 iaitu dengan kadar $86.3 \%{ }^{36}$ Laporan Measuring Tax Gap yang dikeluarkan oleh kerajaan Britain adalah begitu terperinci berserta metodologi kajian yang boleh dicontohi oleh negara-negara lain.

Kajian mengenai jurang cukai ini memberi panduan bagi membangunkan jurang kutipan zakat. Pengalaman dari dua negara yang menghasilkan laporan jurang cukai menunjukkan bahawa usaha ini bukan merupakan sesuatu yang mudah di mana IRS menyatakan "Tax gap estimates take years to produce". ${ }^{37}$ Pengalaman ini memberikan dua petunjuk kepada kajian ini iaitu jurang cukai memberikan maklumat yang sangat penting yang perlu diperoleh bagi

34 P. Shome, 'The Control of Tax Evasion and the Role of Tax Administration,' dalam Tax Systems and Tax Reforms in South and East Asia, ed. L Bernardi et al., (New York: Routledge, 2006), 40.

35 Government of UK, 'Measuring Tax Gap 2013,' https://www.gov.uk/government/ publications/measuring-tax-gaps, diakses pada 12 Disember 2013.

36 Internal Revenue Service (IRS) Amerika Syarikat, http://www.irs.gov/uac/IRSReleases-New-Tax-Gap-Estimates;-Compliance-Rates-Remain-StatisticallyUnchanged-From-Previous-Study, diakses pada 12 Disember 2013.

37 Internal Revenue Service (IRS) Amerika Syarikat, http://www.irs.gov/uac/IRSReleases-2006-Tax-Gap-Estimates, diakses pada 12 Disember 2013. 
merangka pungutan cukai yang efektif. Petunjuk kedua adalah kajian jurang cukai ini bukan sesuatu yang mudah tetapi tidak mustahil untuk dihasilkan.

Institusi zakat di Malaysia membuat analisis pencapaian dalam bentuk pembentangan statistik kutipan dan bilangan pembayar zakat dengan menunjukkan peningkatan saban tahun. Pelaporan yang dibuat tidak dalam bentuk analisis perbezaan di antara potensi dan pencapaian. Amalan ini adalah satu usaha yang baik tetapi pelaporan sebegini tidak dapat memberi gambaran sebenar terhadap pencapaian sebenar berbanding potensi yang sepatutnya diperolehi. Selain itu, pelaporan sedia ada tidak dapat mengukur tahap penetrasi pasaran ${ }^{38}$ kutipan zakat. Usaha untuk menghasilkan jurang zakat ada dibuat melalui kajian kepatuhan berzakat. Walaupun kajian-kajian ini tidak menggunakan istilah jurang zakat, tetapi hasil kajiannya adalah untuk menunjukkan perbezaan di antara potensi dengan prestasi sebenar. Terdapat dua kajian yang membuat kajian terperinci bagi menganalisis potensi kutipan.

Mohd Yahya Mohd Hussin, Fidlizan Muhammad dan Mohammad Ali Roshidi membuat kajian terhadap kepatuhan zakat fitrah. Kajiannya mendapati walaupun kutipan zakat fitrah sentiasa meningkat tetapi dari segi bilangan pembayar yang tidak membayar juga tinggi. Selain itu, kajian ini turut mendapati ketirisan kutipan sebanyak $20.62 \%$ hingga $44.85 \%$ bagi tempoh 16 tahun iaitu tahun 1995-2011. ${ }^{39}$ Kajian ini juga menunjukkan kadar ketirisan adalah smakin menurun. Ini adalah petanda yang baik terhadap trend pembayaran zakat fitrah.

Ahmad Shahir Makhtar dan Adibah Abdul Wahab turut membuat kajian terhadap potensi kutipan zakat di negeri Selangor berasaskan kepada bilangan penduduk, bilangan syarikat dan purata pembayaran. Berdasarkan kepada anggaran 30\% adalah layak menunaikan zakat, jumlah kutipan zakat adalah sebanyak RM0.5 bilion. ${ }^{40}$ Selain itu juga, kajian ini turut membuat jurang kutipan zakat dari aspek bilangan pembayar dan kutipan zakat bagi tahun 2010. Dari aspek pembayar zakat, pencapaian kepatuhan adalah sebanyak $39.24 \%$ bagi individu dan $33.33 \%$ bagi syarikat. Dari aspek jumlah kutipan zakat, jumlah kutipan 2010 adalah 57\% daripada potensi. Ini adalah cubaan yang baik dan boleh dicontohi bagi kajian ini. Namun begitu, bagi tujuan

38 Kenneth E. Clow \& Donald Baack, Marketing Management A Customer-Oriented Approach (Carlifornia: Sage Publication Inc: 2010), 44.

39 Mohd Yahya Mohd Hussin, Fidlizan Muhammad \& Mohammad Ali Roshidi, 'Kepatuhan Membayar Zakat: Analisis Kutipan dan Ketirisan Zakat Fitrah di Selangor,' Jurnal Syariah, 21/2 (2013): 202-203.

40 Ahmad Shahir Makhtar \& Adibah Abdul Wahab, 'Pengurusan Zakat di Negeri Selangor: Isu dan Cabaran,' (Prosiding Konvensyen Kebangsaan Perancangan \& Pengurusan Harta dalam Islam, UKM, Julai 2010). 
mendapatkan jumlah potensi kajian ini menggunakan andaian 30\% layak dan menggunakan purata bayaran dan bukan jumlah sebenar.

Berdasarkan kajian literatur, analisis potensi kutipan zakat masih sangat kurang dan perlu diperkayakan. Selain itu, skop kajian potensi kutipan yang pernah diadakan adalah berbeza dengan skop kajian ini di mana kajian ini memilih segmen PLC sebagai fokus kajian. Metodologi kajian lalu adalah menggunakan andaian tertentu sahaja dan hasil yang dibuat adalah berdasarkan kepada anggaran kasar dan tidak menggunakan kaedah bancian kepada populasi sebenar. Kajian yang lalu menggnakan pendekatan tersendiri dalam mengenalpasti perbezaan di antara di antara kutipan sebenar dengan potensi. Selain itu, tiada lagi kajian khusus dibuat bagi segmen PLC terutama dalam konteks melihat potensi kutipan zakat segmen ini seterusnya mendapatkan jurang kutipan yang wujud di dalam segmen pasaran ini. Ini akan menjadi sumbangan kepada industri zakat di Malaysia tambahan skop kajian ini adalah mencakupi seluruh negara.

\section{METODOLOGI}

\section{Kerangka kajian}

Kajian ini adalah kajian penerokaan di mana kerangka kajian ini dibangunkan dari konsep jurang cukai sebagaimana yang dijelaskan dalam perbincangan di atas. Dalam konteks jurang cukai, dua komponen yang paling penting untuk diperolehi iaitu potensi dan pencapaian semasa. Apabila kedua-dua komponen ini dapat diperolehi, maka jurang zakat akan dapat dihasilkan. Melalui pendekatan kuantitatif, kajian yang dibuat secara keratan rentas (crosssectional study) ini akan membuat enam analisis utama. Ia diilustrasikan melalui Rajah 1.

\section{Populasi kajian}

Populasi kajian ini adalah PLC yang sahamnya dikategorikan sebagai patuh Syariah yang disenaraikan di Bursa Malaysia melalui penerbitan khas Suruhanjaya Sekuriti Malaysia iaitu Senarai Sekuriti Patuh Syariah oleh Majlis Penasihat Syariah Suruhanjaya Sekuriti Malaysia yang dikemas kini dua kali setahun. Kajian ini menggunakan Senarai Sekuriti Patuh Syariah yang berkuatkuasa 30 November 2012 di mana sebanyak 817 syarikat (89\%) diluluskan sebagai syarikat patuh Syariah daripada keseluruhan syarikat iaitu 
923 syarikat. ${ }^{41}$ Semua syarikat termasuk dalam skop kajian sama ada syarikat tersenarai di papan utama dan papan kedua.

\section{Pengumpulan dan Analisis Data}

Bagi tujuan mengenal pasti pemilikan muslim, laporan tahunan terbaru semasa proses muat turun laporan diambil mulai bulan Januari hingga Mac 2013. Daripada 817 syarikat patuh Syariah, sebanyak 705 laporan tahunan terkini dapat dimuat turun iaitu sebanyak $86.3 \%$ daripada jumlah keseluruhan syarikat. Sebanyak 112 syarikat tidak diperoleh kerana pelbagai faktor terutama kerana laman web tidak dikemas kini, sedang diselenggara dan laporan tahunan tidak tersedia untuk dimuat turun. Sebanyak 515 laporan $(73.1 \%)$ yang diperoleh adalah bagi tahun 2012, 160 laporan (26.7\%) bagi tahun 2013 dan 30 laporan (4.2\%) bagi tahun 2011. Oleh itu, terdapat perbezaan tahun kewangan yang diambil bagi tujuan ini iaitu dalam julat 2011-2013. Walaupun terdapat perbezaan tahun tetapi kajian ini mengutamakan maklumat yang terbaru untuk diguna pakai bagi memastikan kualiti maklumat yang diperoleh.

Proses penentuan saham milik muslim di dalam PLC adalah sesuatu rumit kerana pemilikan bertukar setiap masa kerana keadaan saham yang sentiasa didagangkan. Namun begitu, mengikut amalan Lembaga Zakat Selangor $(\text { MAIS })^{42}$ penentuan pemilikan Muslim ini dilakukan dengan merujuk kepada laporan pemilik saham tertinggi yang perlu dilaporkan oleh syarikat di dalam laporan tahunan. Pemilikan yang diambil kira adalah pemilikan individu muslim dan pemilikan syarikat berkaitan kerajaan (GLC) dan syarikat pelaburan berkaitan kerajaan (GLIC) seperti Kumpulan Wang Simpanan Pekerja (KWSP), Tabung Haji (TH), Permodalan Nasional Berhad (PNB), Kumpulan Wang Amanah Pencen (KWAP), Kementerian Kewangan Diperbadankan dan Khazanah Nasional. ${ }^{43}$ Bagi syarikat yang mempunyai pemilikan Muslim kurang daripada $30 \%$, berdasarkan kepada pengalaman institusi zakat, adalah sukar untuk pemegang saham melunaskan zakat perniagaan melalui syarikat dan menggunakan dana syarikat. Mereka disarankan untuk membayar zakat secara persendirian di bawah kategori zakat saham. ${ }^{44}$

Bagi tujuan kajian ini, kedudukan pemilikan Muslim bagi sesebuah syarikat diperolehi melalui laporan 30 pemegang saham tertinggi (30 largest

41 Suruhanjaya Sekuriti Malaysia, Senarai Sekuriti Patuh Syariah 2012, 9.

42 Mohd Sabirin Sarbini (Pengurus Sektor Perniagaan, Lembaga Zakat Selangor MAIS), dalam temu bual beliau bersama penulis, pada 5 Jun 2012.

43 Khazanah Nasional, http://www.khazanah.com/faq.htm, diakses pada 1 Jun 2015.

44 Lembaga Zakat Selangor, http://www.zakatselangor.com.my/jenis-jenis-zakat/ zakat-harta/zakat-saham/, diakses pada 1 Jun 2012. 
shareholders) yang dilaporkan di dalam bab Analysis of Shareholdings di dalam setiap laporan. Berdasarkan kepada senarai ini pemilik Muslim sama ada individu atau syarikat dapat dikenalpasti beserta peratus pegangan masing-masing dan jumlah peratus pegangan bagi setiap syarikat. Kajian ini membahagikan pemilikan Muslim kepada empat kategori iaitu melebihi 50\%, $30 \%-49 \%, 1 \%-29 \%$ dan $0 \%$. Kajian ini menetapkan syarikat yang mempunyai pemilikan muslim sebanyak $30 \%$ dan ke atas adalah dikira syarikat yang dimiliki oleh Muslim dan layak untuk membayar zakat perniagaan. Pemilikan syarikat berkaitan kerajaan (GLC) dan syarikat pelaburan berkaitan kerajaan (GLIC) dikategorikan sebagai pemilikan Muslim. Penetapan ini adalah berdasarkan kepada amalan institusi zakat yang menjadi sandaran kepada amalan zakat bagi kajian ini iaitu Lembaga Zakat Selangor ${ }^{45}$ dan Pusat Pungutan Zakat, Majlis Agama Islam Wilayah Persekutuan. ${ }^{46}$

Seterusnya kajian ini mengenal pasti potensi kutipan zakat yang boleh dipungut daripada sektor PLC dengan membuat anggaran zakat yang dikenakan kepada setiap syarikat. Proses ini dilakukan pada bulan April hingga Mei 2013. Proses ini dibuat dengan membuat taksiran zakat pernigaan ke atas setiap syarikat Muslim yang dikenal pasti. Pengiraan zakat dibuat berasaskan buku Panduan Zakat di Malaysia ${ }^{47}$ dengan merujuk amalan Lembaga Zakat Selangor (LZS) ${ }^{48}$ dan Pusat Pungutan Zakat, Majlis Agama Islam Wilayah Persekutuan. ${ }^{49}$ Taksiran dibuat menggunakan kaedah Modal Berkembang iaitu dengan mengambil kira ekuiti pemilik entiti perniagaan tersebut, sumbersumber pembiayaan kewangan dan dibuat pelarasan sama ada dicampur atau sebaliknya. Dalam istilah ringkas ialah Modal dicampurkan dengan Keuntungan. Persamaan dari aspek perakaunan digambarkan sebagaimana berikut:

Ekuiti Pemilik + Liabiliti Jangka Panjang - Aset tetap Aset Bukan Semasa $+/$ - Pelarasan $=$ harta perniagaan yang dikenakan zakat. ${ }^{50}$

45 Mohd Sabirin Sarbini (Pengurus Sektor Perniagaan, Lembaga Zakat Selangor MAIS), dalam temu bual beliau bersama penulis, pada 5 Jun 2012.

46 Khairulazhar Samsudin (Timbalan Pengurus Besar Operasi, Pusat Pungutan Zakat-MAIWP), dalam temu bual beliau bersama penulis, pada 4 Februari 2012.

47 Jabatan Kemajuan Islam Malaysia, Panduan Zakat di Malaysia (Kuala Lumpur: JAKIM, 2001), 19-65.

48 Lembaga Zakat Selangor, Panduan Zakat Perniagaan, 2007. 19-25.

49 Pusat Pungutan Zakat Wilayah Persekutuan, Zakat Perniagaan, http://www.zakat. com.my/info-zakat/jenis-zakat/zakat-perniagaan, diakses pada 1 Jun 2012.

50 Jabatan Kemajuan Islam Malaysia, Panduan Zakat di Malaysia, 2001, 28-29 
Zakat yang ditaksirkan bagi setiap syarikat dijumlahkan bagi memperolehi jumlah zakat yang dikenakan. Amaun yang dijumlahkan ini menjadikan jumlah nilai potensi kutipan zakat bagi segmen PLC di Malaysia.

Kajian ini turut menganalisis jumlah pembayaran zakat oleh PLC dengan mengekstrak maklumat dan amaun pembayaran zakat oleh PLC daripada laporan tahunan yang diperolehi melalui Penyata Untung Rugi (Profit and Loss Statement). Pembayaran zakat yang dikenalpasi bagi setiap syarikat dijumlahkan bagi memperolehi jumlah keseluruhan zakat yang telah dibayar. Selain itu bilangan syarikat yang membuat pembayaran zakat dikenalpasti. Oleh itu, bilangan syarikat yang patuh kepada pembayaran zakat dapat dikenalpasti. Jurang zakat diperoleh daripada perbezaan di antara potensi dan kutipan zakat sebenar. Langkah pengumpulan dan analisis data bagi kajian ini diilustrasikan melalui Rajah 1.

Rajah 1: Langkah Pengumpulan dan Analisis Data

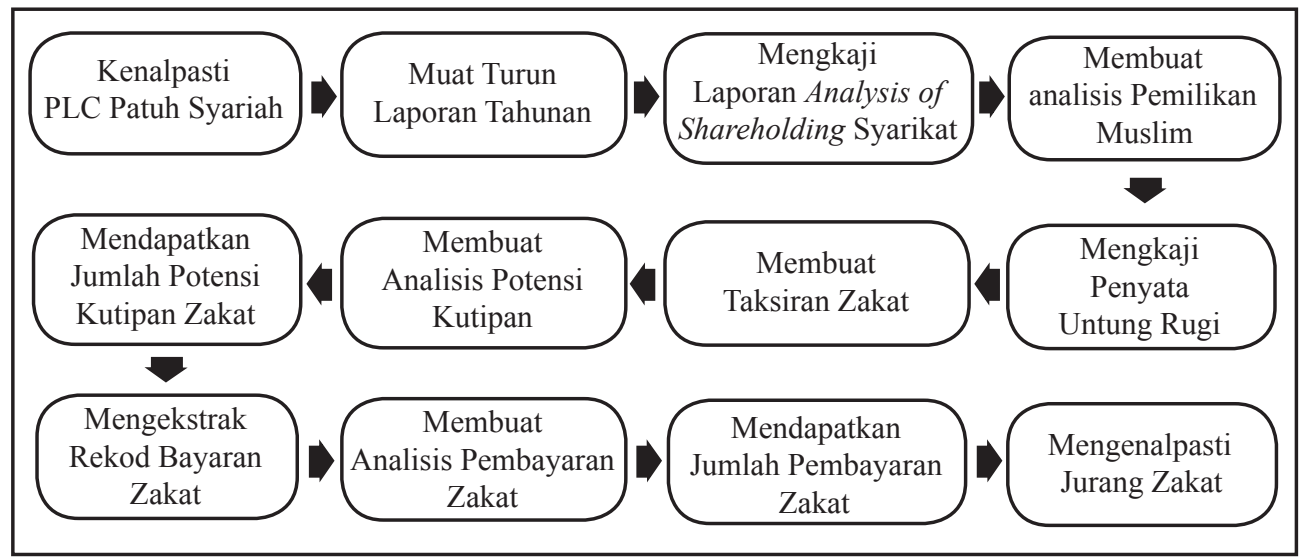

Sumber: Analisis Kajian.

\section{DAPATAN KAJIAN}

Berdasarkan kepada analisis yang dilakukan bagi mencapai objektif kajian, terdapat enam dapatan utama kajian sebagaimana berikut:

\section{Analisis Kedudukan Pemilikan Muslim dalam PLC}

Analisis pemilikan muslim dibuat terhadap setiap syarikat dan peratus pemilikan muslim dapat diperoleh. Didapati sebanyak 69 syarikat $(9.79 \%)$ mempunyai pemilikan muslim melebihi 50\% manakala 49 syarikat (6.95\%) 
mempunyai pemilikan 30-49\% muslim. Ini menjadikan syarikat yang layak membayar zakat perniagaan adalah sebanyak 118 syarikat (16.73\%). Majoriti PLC iaitu 443 syarikat $(62.83 \%)$ berada dalam kategori pemilikan muslim 1-29\%. Manakala baki iaitu sebanyak 146 syarikat (20.71\%) tidak mempunyai sebarang pemilikan muslim. Dapatan ini diterangkan perinciannya melalui Jadual 3.

Jadual 3: Kedudukan Pemilikan Muslim Dalam PLC

\begin{tabular}{|c|c|c|c|c|c|c|}
\hline \multirow{2}{*}{ Sektor } & \multirow{2}{*}{$\begin{array}{c}\text { Sekuriti } \\
\text { Patuh } \\
\text { Syariah }\end{array}$} & \multirow{2}{*}{$\begin{array}{c}\text { Syarikat } \\
\text { Yang } \\
\text { Diperoleh } \\
\text { Status } \\
\text { Pemilikan }\end{array}$} & \multicolumn{4}{|c|}{ Peratus Pemilikan Muslim } \\
\hline & & & $\geq 50 \%$ & $30-49 \%$ & $1-29 \%$ & $0 \%$ \\
\hline Barangan Pengguna & 125 & 124 & 4 & 5 & 84 & 31 \\
\hline Barangan Industri & 253 & 234 & 10 & 11 & 163 & 52 \\
\hline Perlombongan & 1 & 1 & 0 & 0 & 0 & 1 \\
\hline Pembinaan & 43 & 43 & 9 & 1 & 29 & 4 \\
\hline $\begin{array}{l}\text { Dagangan/ } \\
\text { Perkhidmatan }\end{array}$ & 178 & 153 & 28 & 20 & 80 & 25 \\
\hline Hartanah & 74 & 73 & 5 & 3 & 52 & 13 \\
\hline Perladangan & 39 & 39 & 3 & 3 & 21 & 12 \\
\hline Teknologi & 95 & 29 & 5 & 5 & 11 & 8 \\
\hline Infrastruktur & 7 & 7 & 3 & 1 & 3 & 0 \\
\hline Kewangan & 2 & 2 & 2 & 0 & 0 & 0 \\
\hline Hotel & 0 & 0 & 0 & 0 & 0 & 0 \\
\hline Dana Tertutup & 0 & 0 & 0 & 0 & 0 & 0 \\
\hline Jumlah & 817 & 705 & 69 & 49 & 443 & 146 \\
\hline Peratus & & & 9.79 & 6.95 & 62.83 & 20.71 \\
\hline
\end{tabular}

Sumber: Analisis Kajian.

Kajian ini turut membuat analisis mengikut lokasi negeri. Penentuan negeri dibuat mengikut alamat lokasi ibu pejabat. Pelaporan dibuat mengikut sama ada Kuala Lumpur, Selangor dan lain-lain negeri. Kuala Lumpur mempunyai bilangan PLC paling tinggi iaitu 60 buah syarikat yang mana 40 daripadanya di bawah kategori pemilikan muslim melebihi 50\% dan 20 syarikat bagi kategori pemilikan muslim 30 - 49\%. Ia diikuti dengan negeri Selangor iaitu 50 buah syarikat yang mana 24 syarikat adalah di bawah kategori pemilikan lebih $50 \%$ dan 26 syarikat di bawah kategori pemilikan muslim 30 - 49\%. Jumlah 
PLC di kedua negeri ini adalah berjumlah 110 syarikat iaitu merangkumi 93.28\% daripada jumlah keseluruhan syarikat iaitu 118 buah syarikat. Hanya $8(6.78 \%)$ syarikat sahaja berada di negeri-negeri lain. Perinciannya dibuat melalui Jadual 4.

Jadual 4: Bilangan PLC Milik Muslim Mengikut Kategori Pemilikan dan Negeri

\begin{tabular}{lclrlrl}
\hline & $\begin{array}{c}\text { Melebihi 50\% } \\
\text { (bilangan) }\end{array}$ & \multicolumn{2}{c}{$\begin{array}{c}30-49 \% \\
\text { (bilangan) }\end{array}$} & \multicolumn{2}{c}{$\begin{array}{c}\text { Jumlah } \\
\text { (bilangan) }\end{array}$} \\
\hline Wilayah Persekutuan & 40 & $(57.97 \%)$ & 20 & $(40.82 \%)$ & 60 & $(50.85 \%)$ \\
Selangor & 24 & $(34.78 \%)$ & 26 & $(53.06 \%)$ & 50 & $(42.37 \%)$ \\
Lain-lain negeri & 5 & $(7.25 \%)$ & 3 & $(6.12 \%)$ & 8 & $(6.78 \%)$ \\
\hline Jumlah & 69 & $(100.00 \%)$ & 49 & $(100.00 \%)$ & 118 & $(100.00 \%)$ \\
\hline
\end{tabular}

Sumber: Analisis Kajian

\section{Analisis Kelayakan Membayar Zakat}

Saringan seterusnya yang dibuat adalah dengan membuat taksiran zakat ke atas syarikat yang layak. Sebanyak 91 buah syarikat $(76.5 \%)$ didapati melebihi nisab ${ }^{51}$ dan layak di zakat sebagaimana dinyatakan di dalam Jadual 5. Sebanyak 26 syarikat mempunyai aset semasa bersih kurang daripada nisab yang mana syarikat ini dikira tidak wajib untuk membayar zakat dan tiada syarikat yang layak membayar zakat melalui sektor Perladangan. Ini menjadikan analisis yang dibuat adalah terhadap sembilan sektor iaitu Barangan Pengguna, Barangan Industri, Pembinaan, Dagangan/Perkhidmatan, Hartanah, Perladangan, Teknologi, Infrastruktur dan Kewangan. Sebanyak 57 syarikat yang layak di bawah kategori pemilikan Muslim melebihi 50\%, manakala sebanyak 34 syarikat bagi kategori 30-49\% Muslim.

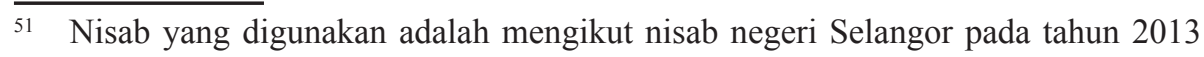
iaitu RM13,000. 
Jurnal Syariah, Jil. 24, Bil. 2 (2016) 207-236

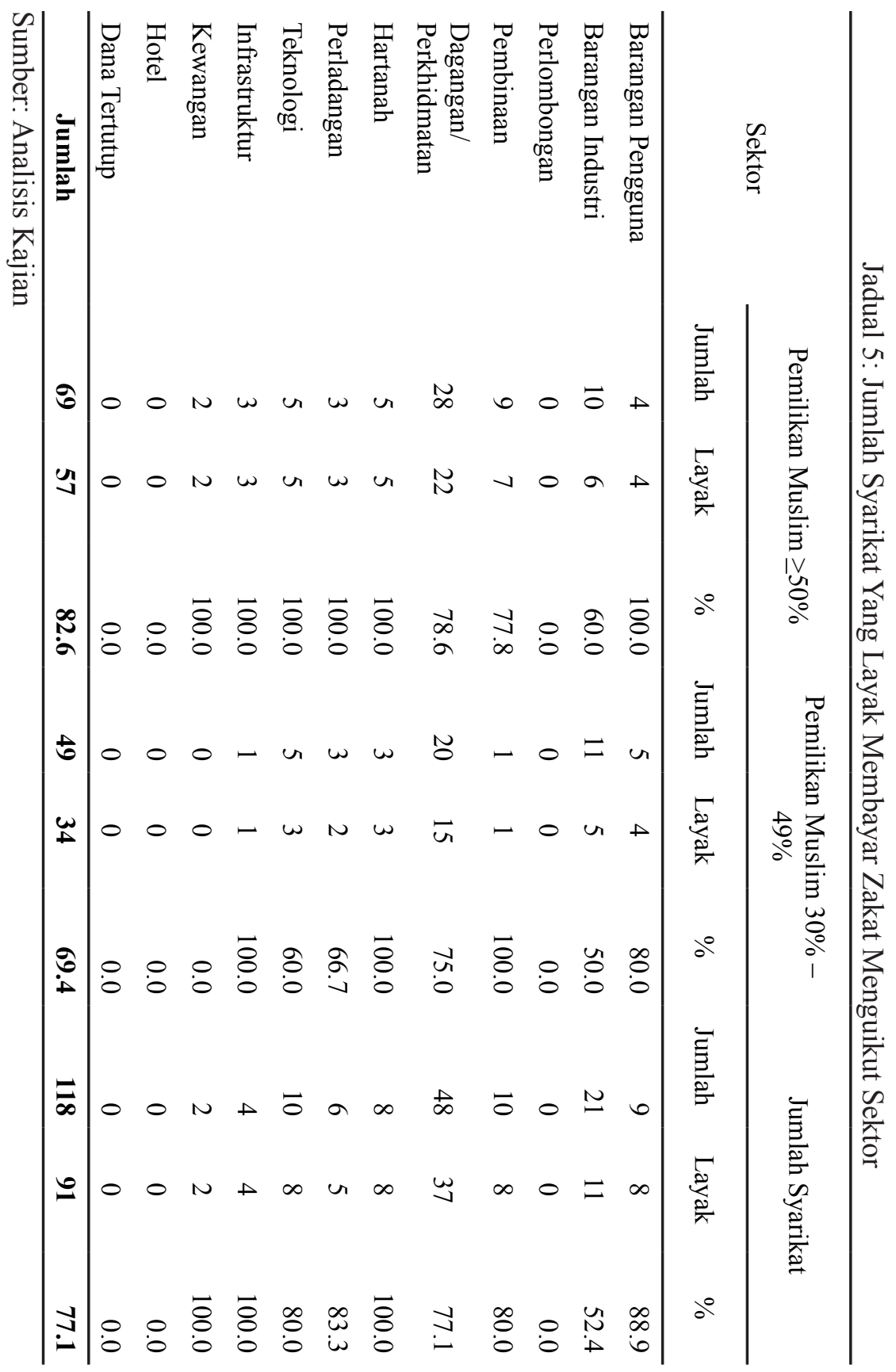




\section{Analisis Taksiran Zakat}

Hasil daripada maklumat taksiran zakat yang dibuat ke atas 91 buah syarikat mendapati, jumlah zakat yang dikenakan adalah berbeza dan dalam julat yang sangat besar. Lima syarikat yang mempunyai jumlah zakat paling tinggi iaitu Petronas Gas Berhad iaitu RM26,219,489.38, Axiata Group Berhad iaitu RM45,188,315.58, MISC iaitu RM16,080,906.87, SP Setia Berhad iaitu 20,827,128.01 dan Felda Global Ventures iaitu RM67,766,729.59. Jumlah ini adalah anggaran berasaskan item dalam laporan tahunan sahaja. Dalam keadaan sebenar, penerangan daripada pegawai kewangan syarikat dan dokumen sokongan yang lain mengikut kesesuaian digunakan bagi mendapatkan jumlah sebenar zakat yang dikenakan. Lima syarikat yang dikenakan zakat paling rendah iaitu Redtone International Berhad sebanyak RM3,468.47, Lebtech Bhd sebanyak RM3,264.46, SPK-Sentosa Corporation Bhd sebanyak RM1,752.45, PFCE Bhd sebanyak RM1,190.83 dan Petra Energy Bhd sebanyak RM461.97.

\section{Analisis Potensi Kutipan Zakat}

Potensi kutipan zakat bagi segmen PLC diketahui dengan mendapatkan jumlah zakat yang dikenakan kepada 91 buah syarikat yang layak. Ia dihasilkan melalui proses analisis taksiran zakat yang mana setiap syarikat ditaksirkan zakatnya berdasarkan kepada maklumat dalam laporan kewangan syarikat. Analisis potensi ini dibuat mengikut sektor supaya lebih jelas pembahagiannya. Sektor Dagangan/Perkhidmatan merupakan penyumbang utama iaitu 44.65\% dengan jumlah zakat sebanyak RM128.5 juta. Ia diikuti oleh sektor Perladangan (26.21\%) dengan kutipan sebanyak RM75.4 juta, Sektor Barangan Industri (11.37\%) dengan kutipan sebanyak RM32.7 juta dan diikuti dengan Sektor Hartanah (10.15\%) iaitu dengan jumlah kutipan RM29.2 juta sebagaimana dinyatakan di dalam Jadual 6.

Jumlah keseluruhan zakat yang dikenakan bagi 91 buah syarikat ini adalah berjumlah RM291.49 juta. Potensi ini juga menunjukkan jumlah maksimum yang boleh dipungut dari segmen ini. Analisis ini menjadi lebih signifikan apabila analisis jurang kutipan zakat dibuat. 
Jadual 6: Potensi Kutipan Zakat Mengikut Sektor

\begin{tabular}{lccrc}
\hline \multicolumn{1}{c}{ Sektor } & $\begin{array}{c}\text { Syarikat } \\
\text { Milik } \\
\text { Muslim }\end{array}$ & $\begin{array}{c}\text { Syarikat } \\
\text { Layak } \\
\text { Dizakat }\end{array}$ & Jumlah Zakat & $\begin{array}{c}\text { Kadar } \\
\text { Sumbangan } \\
\text { Sektor }\end{array}$ \\
\hline Barangan Pengguna & 9 & 8 & $14,449,103.80$ & 5.02 \\
Barangan Industri & 21 & 11 & $32,692,165.26$ & 11.37 \\
Pembinaan & 10 & 8 & $1,084,772.73$ & 0.38 \\
Dagangan/Perkhidmatan & 48 & 37 & $128,409,313.31$ & 44.65 \\
Hartanah & 8 & 8 & $29,195,884.28$ & 10.15 \\
Perladangan & 6 & 5 & $75,392,378.59$ & 26.21 \\
Teknologi & 10 & 8 & $2,387,103.87$ & 0.83 \\
Infrastruktur & 4 & 4 & $3,998,136.45$ & 1.39 \\
Kewangan & 2 & 2 & $3,884,268.56$ & 1.35 \\
\hline \multicolumn{1}{c}{ Jumlah } & $\mathbf{1 1 8}$ & $\mathbf{9 1}$ & $\mathbf{2 9 1 , 4 9 3 , 1 2 6 . 8 5}$ & \\
\hline
\end{tabular}

Sumber: Analisis Kajian

\section{Analisis Pembayaran Zakat}

Berdasarkan kepada maklumat laporan kewangan, hanya terdapat 15 syarikat (16.5\%) sahaja yang menyatakan pembayaran zakat dan melaporkannya di dalam Laporan Tahunan masing-masing iaitu sebagaimana di dalam Jadual 6. Tenaga Nasional Bhd mempunyai rekod pembayaran zakat paling tinggi iaitu sebanyak RM26.5 juta diikuti oleh Felda Global Ventures Berhad iaitu sebanyak RM15.58 juta dan diikuti oleh BIMB Holdings Berhad iaitu RM10.12 juta. Jumlah keseluruhan zakat yang dibayar adalah sebanyak RM 75.85 juta. 
Jadual 7: Senarai PLC yang Membayar Zakat 2012

\begin{tabular}{|c|c|c|c|c|}
\hline Sektor & $\begin{array}{c}\text { Bilangan } \\
\text { Syarikat } \\
\text { Bayar } \\
\text { Zakat }\end{array}$ & Nama Syarikat & $\begin{array}{l}\text { Pembayaran } \\
\text { Zakat (RM) }\end{array}$ & $\begin{array}{c}\text { Jumlah } \\
\text { Zakat } \\
\text { (RM) }\end{array}$ \\
\hline $\begin{array}{l}\text { Barangan } \\
\text { Pengguna }\end{array}$ & 1 & $\begin{array}{l}\text { MSM M'sia Holdings } \\
\text { Bhd. }\end{array}$ & $6,398,000$ & $6,398,000$ \\
\hline $\begin{array}{l}\text { Barangan } \\
\text { Industri }\end{array}$ & 0 & - & 0 & 0 \\
\hline Perlombongan & 0 & - & 0 & 0 \\
\hline Pembinaan & 1 & Merge Energy Bhd & 259,390 & 259,390 \\
\hline \multirow{8}{*}{$\begin{array}{l}\text { Dagangan/ } \\
\text { Perkhidmatan }\end{array}$} & 8 & Axiata Group Bhd. & $8,500,000$ & $42,115,000$ \\
\hline & & Faber Group Bhd & $1,500,000$ & \\
\hline & & MMC Corporation Bhd. & $1,705,000$ & \\
\hline & & KPJ Healthcare Bhd & $1,320,000$ & \\
\hline & & Pharmaniaga Bhd. & 350,000 & \\
\hline & & Telekom Malaysia Bhd & $2,200,000$ & \\
\hline & & Tenaga Nasional Bhd & $26,500,000$ & \\
\hline & & Utusan Melayu Bhd & 40,000 & \\
\hline Hartanah & 0 & - & 0 & 0 \\
\hline \multirow[t]{2}{*}{ Perladangan } & 2 & $\begin{array}{l}\text { Felda Global Ventures } \\
\text { Bhd. }\end{array}$ & $16,580,000$ & $16,989,000$ \\
\hline & & TH Plantation Berhad & 409,000 & \\
\hline Teknologi & 1 & Mesiniaga Bhd & 180,000 & 180,000 \\
\hline Infrastruktur & 0 & & 0 & 0 \\
\hline \multirow[t]{2}{*}{ Kewangan } & 2 & BIMB Holdings Bhd & $10,121,000$ & $10,910,000$ \\
\hline & & $\begin{array}{l}\text { Sykt. Takaful Malaysia } \\
\text { Bhd }\end{array}$ & 789,000 & \\
\hline Hotel & 0 & - & 0 & 0 \\
\hline Dana Tertutup & 0 & - & 0 & 0 \\
\hline Jumlah & 15 & & $76,851,390$ & $76,851,390$ \\
\hline
\end{tabular}

Sumber: Analisis Kajian. 


\section{Jurang Kutipan Zakat}

Jurang kutipan zakat diperoleh dengan mendapatkan perbezaan di antara potensi kutipan zakat dengan kutipan zakat sebenar yang dibayar. Jurang Kutipan Zakat mengikut sektor adalah sebagaimana dalam Jadual 7. Sektor Dagangan/Perkhidmatan mempunyai jurang zakat paling tinggi iaitu RM117 juta diikuti sektor Perladangan iaitu RM59.4 juta. Keseluruhan jurang kutipan zakat adalah sebanyak RM214.6 juta setahun iaitu pada kadar 74\%. Apabila dibuat perbandingan dengan jurang cukai yang diperoleh di Britain iaitu pada kadar 7 hingga 7.1\% sahaja, maka kadar jurang zakat yang diperoleh adalah sangat besar dan luas.

Jadual 7: Analisis Jurang Zakat

\begin{tabular}{lcrrr}
\hline \multicolumn{1}{c}{ Sektor } & $\begin{array}{c}\text { Syarikat } \\
\text { Layak di } \\
\text { Zakat }\end{array}$ & Jumlah zakat & $\begin{array}{c}\text { Pembayaran } \\
\text { Zakat }\end{array}$ & Jurang Zakat \\
\hline Barangan Pengguna & 8 & $14,449,103.80$ & $6,398,000.00$ & $8,051,103.80$ \\
Barangan Industri & 11 & $32,692,165.26$ & 0.00 & $32,692,165.26$ \\
Perlombongan & 0 & 0.00 & 0.00 & 0.00 \\
Pembinaan & 8 & $1,084,772.73$ & $259,390.00$ & $825,382.73$ \\
Dagangan/ & 37 & $128,409,313.31$ & $42,115,000.00$ & $86,294,313.31$ \\
Perkhidmatan & 8 & $29,195,884.28$ & 0.00 & $29,195,884.28$ \\
Hartanah & 5 & $75,392,378.59$ & $16,989,000.00$ & $59,403,378.59$ \\
Perladangan & 8 & $2,387,103.87$ & $180,000.00$ & $2,207,103.87$ \\
Teknologi & 4 & $3,998,136.45$ & 0.00 & $3,998,136.45$ \\
Infrastruktur & 2 & $3,884,268.56$ & $10,910,000.00$ & $-7,025,731.44$ \\
Kewangan & 0 & 0.00 & 0.00 & 0.00 \\
Hotel & 0 & 0.00 & 0.00 & 0.00 \\
Dana Tertutup & $\mathbf{9 1}$ & $\mathbf{2 9 1 , 4 9 3 , 1 2 6 . 8 5}$ & $\mathbf{7 6 , 8 5 1 , 3 9 0 . 0 0}$ & $\mathbf{2 1 4 , 6 4 1 , 7 3 6 . 8 5}$ \\
\hline \multicolumn{1}{c}{ Jumlah } & & & & $\mathbf{7 3 . 6 3}$ \\
\hline Kadar Jurang (\%) & & & &
\end{tabular}

Sumber: Analisis Kajian. 
Ringkasan dapatan daripada analisis kajian ini dibuat dalam Jadual 8.

Jadual 8: Ringkasan Dapatan Hasil Analisis Kajian

\begin{tabular}{clc}
\hline Bil. & \multicolumn{1}{c}{ Tindakan / Analisis } & Hasil Kajian \\
\hline 1. & Kenalpasti saham patuh syariah & 817 syarikat \\
2. & Muat turun laporan tahunan syarikat & 705 laporan $(86.3 \%)$ \\
3. & Analisis Pemilikan Muslim & 118 syarikat $(16.7 \%)$ \\
4. & Analisis Kelayakan Membayar Zakat & 91 syarikat $(76.5 \%)$ \\
5. & Analisi Pembayaran Zakat & 15 syarikat (16.5\%) \\
6. & Analisi potensi kutipan zakat & RM291.5juta \\
7. & Analisis Kepatuhan Zakat & RM76.8 juta \\
8. & Jurang Zakat & RM214.6 juta \\
9. & Kadar Jurang Zakat & $73.98 \%$ \\
\hline
\end{tabular}

\section{RUMUSAN DAN IMPLIKASI DASAR}

Segmen PLC adalah lubuk emas dalam konteks zakat kerana ia menyediakan pasaran yang lumayan bagi meningkatkan kutipan. Ini dibuktikan dengan jumlah potensi kutipan zakat yang diperolehi dalam hasil kajian ini iaitu hampir RM300 juta. Angka ini adalah begitu besar apabila ia dinisbahkan dengan pelbagai bantuan yang dapat dibuat bagi membantu golongan yang dhaif dan memerlukan bantuan.

Hasil kajian ini juga menunjukkan bahawa segmen PLC ini menyediakan pembayar yang sangat berkualiti dengan purata RM3 juta bagi setiap pembayar. Dalam erti kata lain dengan peningkatan sebuah syarikat, kutipan zakat dapat ditingkatkan sebanyak RM3 juta. Oleh itu, institusi zakat perlu memberikan penekanan kepada segmen ini di samping anak-anak syarikat PLC yang amat berpotensi untuk menjadi sasaran pasaran.

Kajian ini telah berjaya memperkenalkan konsep jurang zakat yang diadaptasi daripada konsep jurang cukai. Kadar jurang zakat sebanyak 74\% adalah amat tinggi berbanding dengan jurang cukai yang hanya pada kadar $7 \%$ di UK. Perbandingan jurang zakat dengan jurang cukai adalah tidak adil kerana senjata cukai adalah penguatkuasaan undang-undang berbanding zakat yang berbentuk sukarela, namun ia dapat memberikan sedikit gambaran untuk 
disesuaikan dalam konteks kepatuhan zakat. Malah, dapatan ini turut boleh dijadikan panduan untuk segmen pasaran lain bagi zakat perniagaan.

Jurang zakat yang tinggi hasil daripada kajian ini memberi isyarat yang positif kepada gerak kerja pemasaran dan dakwah oleh institusi zakat. Jurang yang besar menunjukkan potensi kutipan zakat masih luas melalui segmen ini. Oleh itu, institusi zakat perlu merebut peluang keemasan dan menterjemahkannya dalam bentuk strategi pemasaran yang ampuh bagi menggarap potensi yang ada.

Walaupun tidak dinyatakan secara khusus dalam objektif kajian, dapatan lain yang amat bermanfaat adalah maklumat status sebenar pemilikan ekuiti Muslim atau juga boleh diluaskan kepada pemilikan bumiputera dalam dana pasaran modal di Malaysia iaitu sebanyak 16.7\%. Ini menunjukkan ekuiti Muslim atau bumiputera adalah rendah walaupun pelbagai usaha telah dijalankan oleh pihak kerajaan bagi membaiki prestasi ini. Pemilikan 16.7\% ini adalah termasuk pemilikan kerajaan dan dana awam seperti Kumpulan Wang Simpanan Pekerja (KWSP), Tabung Haji (TH) dan Khazanah Nasional Berhad (Khazanah). Oleh itu, pemilikan oleh individu Muslim adalah sangat kecil dan dikhuatiri ianya akan semakin mengecil. Lantaran itu, usaha untuk meningkatkan pegangan ekuiti bumiputera dalam pasaran saham amat perlu diteruskan supaya keadaan ini dapat diperbaiki. Jika tiada intervensi berkesan dijalankan oleh pihak berwajib, dikhuatiri golongan bumiputera dan Muslim di negara ini akan makin ketinggalan dalam bidang perniagan dan ekonomi.

Kajian ini turut memberikan sumbangan dalam konteks metodologi iaitu dengan memperkenalkan kaedah bancian sebenar terhadap satu-satu kumpulan sasar. Tidak dinafikan ia merupakan satu usaha yang rumit terutama atas kapasiti seorang penyelidik, tetapi dapatan yang terhasil adalah memuaskan kerana hasil kajian diraih daripada setiap unit dalam populasi. Institusi zakat atau pihak yang berautoriti boleh memanfaatkan dan meluaskan kaedah ini kepada segmen lain sebagai usaha untuk memastikan golongan yang wajib membayar zakat melunaskan kewajipan mereka.

Selain itu, kajian ini berjaya memperkenalkan kaedah lain bagi mengukur prestasi kutipan zakat di negara ini iaitu dengan membuat perbandingan pencapaian semasa dengan peluang yang ada. Telah sampai masanya institusi zakat di negara ini membuat pembaharuan dalam bentuk pelaporan prestasi kutipan kerana pengkorporataan institusi zakat di Malaysia telahpun melebihi dua dekad. Pelaporan peningkatan kutipan dan bilangan pembayar yang kini diamalkan adalah merupakan kaedah tradisi yang memerlukan nafas baru. Institusi zakat boleh meneroka pelbagai kaedah pelaporan lain sebagai usaha mempekemaskan gerak kerja institusi zakat agar lebih efektif dan efisien. 


\section{KESIMPULAN}

Objektif utama kajian ini adalah bagi membuat anggaran potensi kutipan zakat dan mengenalpasti jurang zakat dalam segmen PLC. Kajian ini telah berjaya mencapai objektif kajian dengan memperolehi potensi kutipan bagi segmen PLC ini dalah sebanyak hampir RM300 juta. Jumlah ini adalah satu angka yang besar untuk digarap oleh pihak yang berkenaan dalam usaha memaksimumkan lagi kutipan zakat. Kajian ini juga berjaya mengetahui jurang zakat iaitu sebanyak lebih RM200 juta dengan kadar 74\%. Dapatan ini menunjukkan masih banyak syarikat yang belum membayar dan masih banyak potensi yang belum direalisasikan. Pemilikan muslim dan bumiputera dalam pasaran modal sebanyak $16.7 \%$ adalah sesuatu yang serius dan memerlukan tindakan intervensi oleh pihak berwajib untuk menambah baik keadaan ini. 118 syarikat yang mempunyai pemilikan muslim melebihi 30\% amat perlu didekati dengan sewajarnya agar potensi kutipan zakat dapat dioptimumkan. Ketirisan zakat yang ditemui melalui kajian ini merupakan satu kerugian kepada umat Islam lantaran dana zakat adalah salah satu tunggak kekuatan umat Islam. Kajian seumpama ini perlu diteruskan kepada anak syarikat PLC atau segmen pasaran yang lain sehinggalah semua keperluan segmen pasaran pembayaran zakat dapat diperolehi bagi menghasilkan jurang zakat yang lebih menyeluruh dan tidak terhad kepada satu segmen pasaran sahaja seperti kajian ini.

\section{RUJUKAN}

Abdul Hakim Amir Osman, 'Potensi Pembayar dan Kutipan Zakat di Malaysia', (makalah, Persidangan Zakat dan Cukai Peringkat Kebangsaan 2007 Kuala Lumpur, 22-24 Mei 2007).

Abū Dāwūd Sulaymān Ibn al-Ash'ath al-Sijistān \& 'Abd al-Hamīd Muḥammad Muhy al-Dīn, Sunan Abū Dāwūd (Beirūt: Dār al-Fikr, t.t.).

Ahmad Shahir Makhtar \& Adibah Abdul Wahab, 'Pengurusan Zakat di Negeri Selangor: Isu dan Cabaran,' (Prosiding Konvensyen Kebangsaan Perancangan \& Pengurusan Harta dalam Islam, UKM, Julai 2010).

Aznan Hasan, 'Zakat on Shakhșiyyah I'tibāriah (Legal Entity)', (Makalah, Bengkel Zakat Institusi Kewangan Islam, Lanai Kijang, Bank Negara Malaysia, 3 Mei 2011).

Internal Revenue Service (IRS) Amerika Syarikat, http://www.irs.gov/uac/ IRS-Releases-2006-Tax-Gap-Estimates, 12 Disember 2013. 
Internal Revenue Service (IRS) Amerika Syarikat, http://www.irs.gov/uac/ IRS-Releases-New-Tax-Gap-Estimates;-Compliance-Rates-RemainStatistically-Unchanged-From-Previous-Study, 12 Disember 2013.

Jabatan Kemajuan Islam Malaysia, Panduan Zakat di Malaysia (Kuala Lumpur: JAKIM, 2001).

Kenneth E. Clow \& Donald Baack, Marketing Management: A CustomerOriented Approach (Carlifornia: Sage Publcation Inc, 2010).

Khazanah Nasional, 'FAQ' http://www.khazanah.com/faq.htm, diakses pada 1 Jun 2012.

Lembaga Zakat Selangor, 'Zakat Saham', http://www.zakatselangor.com.my/ jenis-jenis-zakat/zakat-harta/zakat-saham/, diakses pada 1 Jun 2012.

Lembaga Zakat Selangor, Panduan Zakat Perniagaan (Shah Alam: Lembaga Zakat Selangor, 2008).

Malik M. Hafeez, 'An Analysis of Corporate Entity and Limited Liability in Islamic and Western Perspectives of Corporate Governance,' International Journal of Business, Economics and Law, 2/3 (2013): 104107.

Mohd Yahya Mohd Hussin, Fidlizan Muhammad \& Mohammad Ali Roshidi, 'Kepatuhan Membayar Zakat: Analisis Kutipan dan Ketirisan Zakat Fitrah di Selangor,' Jurnal Syariah, 21/2 (2013): 202-203.

Government of United Kingdom, 'Measuring Tax Gap 2013,' https://www.gov. uk/government/publications/measuring-tax-gaps, 12 Disember 2013.

Mohd Rais Alias, 'Kepatuhan Perlaksanaan Zakat Perniagaan di Malaysia: Satu Tinjauan Oleh Pusat Pungutan Zakat di Wilayah Persekutan' (Makalah, Persidangan Zakat dan Cukai Kebangsaan Ke 5, Melaka: 14 - 16 Julai 2011).

Mohd Helmi Foad, 'Hampir 80\% Syarikat Islam Tidak Bayar Zakat', laman sesawang Utusan Online, http://www.utusan.com.my/utusan/ info.asp? $\mathrm{y}=2002 \& \mathrm{dt}=0504 \& \mathrm{pub}=$ Utusan_Malaysia\&sec=Dalam Negeri\&pg=dn_05.htm., dicapai pada 31 November 2013.

Monzer Kahf, 'The Performance of Zakah Institution in Theory and Practice' (Makalah, International Conference on Islamic Economics Towards The $21^{\text {st }}$ Century, Kuala Lumpur: 9-12 Ogos 1999).

Muhammad Firdaus, Irfan Syauqi Beik, Tonny Irawan \& Bambang Juanda, 'Economic Estimation and Determinations of Zakat Potential in Indonesia', (IRTI Working Paper Series, Islamic Research and Training Instituti, Islamic Develompen Bank, Jeddah, 2012). 
Muhammad Taqi Usmani, An Introduction to Islamic Finance (Karachi: Idaratul Ma'arif, 1998).

Nasim Shah Sirazi \& Md Fouad, 'Prospects Elimination through Potential Zakat Collection in OIC-member Countries: Reappraised,' Journal of Islamic Economics, Banking and Finance, 6/3 (2010): 66.

P. Shome, 'The Control of Tax Evasion and the Role of Tax Administration' dalam Tax Systems and Tax Reforms in South and East Asia, ed. L Bernardi et al. (New York: Routledge, 2006).

Pusat Pungutan Zakat MAIWP, Laporan Zakat (Kuala Lumpur: MAIWP, 2003).

Pusat Pungutan Zakat MAIWP, Laporan Zakat (Kuala Lumpur: MAIWP, 2004).

Pusat Pungutan Zakat MAIWP, Laporan Zakat (Kuala Lumpur: MAIWP, 2005).

Pusat Pungutan Zakat MAIWP, Laporan Zakat (Kuala Lumpur: MAIWP, 2006).

Pusat Pungutan Zakat MAIWP, Laporan Zakat (Kuala Lumpur: MAIWP, 2007).

Pusat Pungutan Zakat MAIWP, Laporan Zakat (Kuala Lumpur: MAIWP, 2008).

Pusat Pungutan Zakat MAIWP, Laporan Zakat (Kuala Lumpur: MAIWP, 2009).

Pusat Pungutan Zakat MAIWP, Laporan Zakat (Kuala Lumpur: MAIWP, 2010).

Pusat Pungutan Zakat MAIWP, Laporan Zakat (Kuala Lumpur: MAIWP, 2011).

Pusat Pungutan Zakat MAIWP, Laporan Zakat (Kuala Lumpur: MAIWP, 2012).

Suruhanjaya Sekuriti Malaysia, Senarai Sekuriti Patuh Syariah (Kuala Lumpur: Suruhanjaya Sekuriti Malaysia, 2012).

Suruhanjaya Sekuriti Malaysia, 'Statistik Pasaran Modal Islamik,' http://www. sc.com.my/data-statistics/islamic-capital-market-statistics/, dicapai pada 13 Februari 2014.

Sāmi Ramaḍān Sulaymān, 'al-Asās al-Muhāsabiyyah li taqdīr hāṣilāt alZakāh: Dirāsah Tatbīqiyah fĩ Jumhūriyah Miṣr al-‘Arabiyyah', (Tesis Ph.D, Universiti Al-Azhar, 1980) 
The New Straits Times, 'Zakat Not for Companies, Says Tun Abdul Hamid'. http://www.nst.com.my/latest/zakat-not-for-companies-says-tun-abdulhamid-1.313162\#ixzz2o911Anhr, dicapai pada 21 Disember 2013.

\section{Temu bual}

Khairulazhar Samsudin (Timbalan Pengurus Besar Operasi, Pusat Pungutan Zakat-MAIWP), dalam temu bual beliau bersama penulis, pada 4 Februari 2012.

Mohd Sabirin Sarbini (Pengurus Sektor Perniagaan, Lembaga Zakat Selangor MAIS), dalam temu bual beliau bersama penulis, pada 5 Jun 2012. 